\title{
アジア全体の繊維ビジョンについて
}

古畑 昭 郎

1993年の世界の繊維生産は, 3,912万トン（ファイ バー・オルガノン）で，過去10年間年率で $2.4 \%$ の 伸びで拡大. 繊維貿易も1992年は2,855億ドルで, 過 去10年間年率 $10.2 \%$ の伸びである. いうまですなく この伸びは, 東アジアの伸びによるところが大き く，ちなみに世界生産に占める東アジアのシェアは 合繊で $45.6 \%$, 綿糸で $41.9 \%$ ある (1992年).

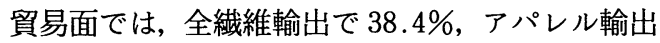
で $42.6 \%$ でった. 1980年代は東アジアのシェアは $30 \%$ 前後であった.

一方，世界における日本のシェアは1980年から 1992年にかけて，合繊生産で 13.0\%から 9.0\%へ, 綿糸生産で $4.1 \%$ から $2.1 \%$ 一低下. 全繊維輸出で $5.5 \%$ から $3 \%$ へ，アパレル輸出で $1.3 \%$ から $0.5 \%$ へとそれぞれ低下している.

1990 年〜2000年の成長率は米国と西欧が各々 $1.8 \% ， 1.7 \%$ と成熟化し，低い伸び率にとどまるの に対し，日本を除くアジアは $4.5 \%$, 特に中国は $5.3 \%$ と高い伸びが見込まれている（表 1).

アジアの世界合計に対する繊維生産量のシェア は，2000年には繊維全体で，60\%前後に達するすの と見込まれている(表 2).

一方, 絨維の需要量の世界に占めるシェアは, 1970年から2000年にかけてアジア全体では1970年の $26 \%$ から 2000 年には $42 \%$ に上昇，日本はシェア $7 \%$ 前後でほぼ一定している（表 3).

繊維需要量シェア $42 \%$ と生産量シェア $60 \%$ との 差約 $20 \%$ は, アジアからその他地域への輸出で消化
世界の繊維輸出に占める東アジアの位置
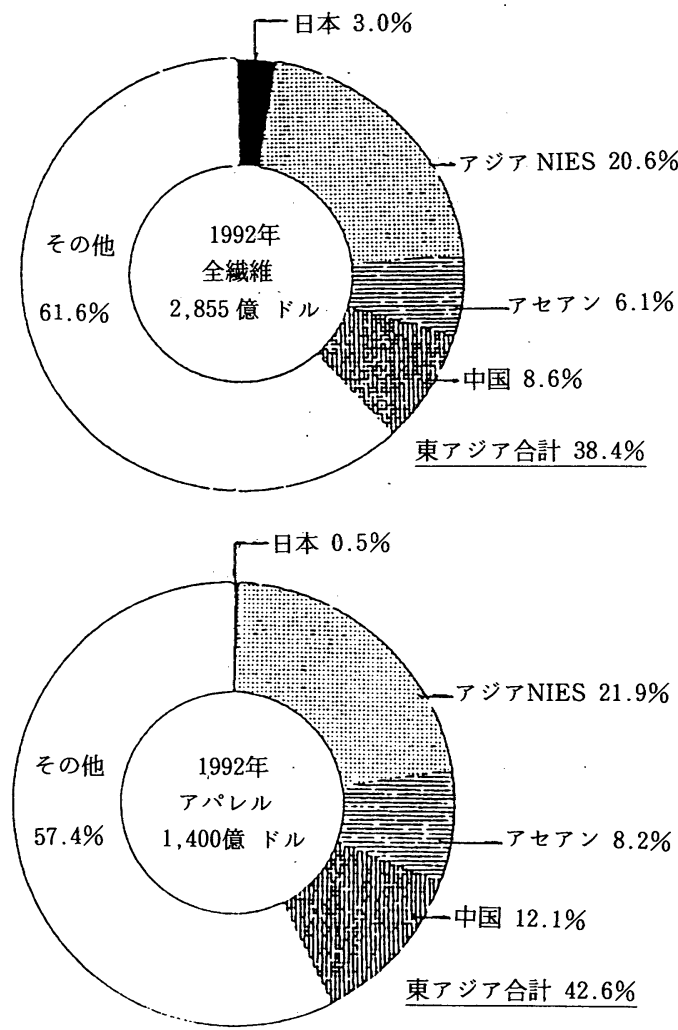

されると考えると，アジアが各国の分業体制を通 し，世界の繊維の一大供給・消費地と位置付けられ る.

しかし，アジア地域外での需要の縮小，地域内で の想定需要の縮小等から, 大規模な供給過剰が表面 
表 1 世界の地域別瀻維需給見通し

\begin{tabular}{|c|c|c|c|c|c|c|c|c|c|c|c|}
\hline & \multicolumn{4}{|c|}{ 織維需要量（千トン） } & \multicolumn{4}{|c|}{ 需要量シェア } & \multicolumn{3}{|c|}{ 年平均伸び率 } \\
\hline 年 & 1970 & 1980 & 1990 & 2000 & 1970 & 1980 & 1990 & 2000 & $80 / 70$ & $90 / 80$ & $00 / 90$ \\
\hline 本 & 1,481 & 1,928 & 2,639 & 3,441 & $6.9 \%$ & $6.6 \%$ & $6.9 \%$ & $7.1 \%$ & $2.7 \%$ & $3.2 \%$ & $2.7 \%$ \\
\hline$\because ゙ \quad$ & 4,145 & 6,950 & 10,801 & 16,717 & 19.3 & 23.7 & 28.2 & 34.5 & 5.3 & 4.5 & 4.5 \\
\hline 暲国 & 146 & 362 & 690 & 1,037 & 0.7 & 1.2 & 1.8 & 2.1 & 9.5 & 6.7 & 4.2 \\
\hline アセアン & 315 & 674 & 850 & 1,377 & 1.5 & 2.3 & 2.8 & 2.8 & 7.9 & 2.3 & 4.9 \\
\hline 中 国 & 1,803 & 3,864 & 6,582 & 11,012 & 8.4 & 13.2 & 22.7 & 22.7 & 7.9 & 5.5 & 5.3 \\
\hline 他アジア & 1,881 & 2,050 & 2,679 & 3,291 & 8.7 & 7.0 & 6.8 & 6.8 & 0.9 & 2.7 & 2.1 \\
\hline 欧 & 4,317 & 5,399 & 6,266 & 7,417 & 20.1 & 18.4 & 16.4 & 15.3 & 2.3 & 1.5 & 1.7 \\
\hline 欧 & 4,018 & 5,368 & 6,272 & 6,081 & 18.7 & 18.3 & 16.4 & 12.5 & 2.9 & 1.6 & -0.3 \\
\hline 州 & 5,789 & 7,043 & 9,038 & 10,851 & 26.9 & 24.0 & 23.6 & 22.4 & 2.0 & 2.5 & 1.8 \\
\hline 米国 & 4,267 & 4,697 & 6,571 & 7,848 & 19.8 & 16.0 & 17.2 & 16.2 & 1.0 & 3.4 & 1.8 \\
\hline その 他 & 1,770 & 2,628 & 3,289 & 3,991 & 8.2 & 9.0 & 8.6 & 8.2 & 4.0 & 2.3 & 2.0 \\
\hline 世界 計 & 21,520 & 29,316 & 38,305 & 48,498 & $100 \%$ & $100 \%$ & $100 \%$ & $100 \%$ & $3.1 \%$ & $2.7 \%$ & $2.4 \%$ \\
\hline
\end{tabular}

（注）「アジア」，「他アジア」は日本と西アジアを含まない.（出所：化繊協会）

*2000年におけるアジア地域（日本を含む）の緎維需要の世界シェアは約 $42 \%$ となる.

表 2 アジアの繊維生産量のシェア（世界計＝100 単位：\%）

\begin{tabular}{|c|c|c|c|c|c|}
\hline 種 別 年 & 1970 & 1980 & 1985 & $1991 / 92$ & 2000 \\
\hline $\begin{array}{lll} & & \text { 系 } \\
\text { 綿 } & \text { 織 } & \text { 物 }\end{array}$ & $\begin{array}{l}40 \\
40\end{array}$ & $\begin{array}{l}46 \\
47\end{array}$ & $\begin{array}{l}49 \\
49\end{array}$ & $\begin{array}{l}58 \\
59\end{array}$ & $\begin{array}{l}60 \\
60\end{array}$ \\
\hline 合繊一原糸・原綿 & 27 & 31 & 38 & 49 & 56 \\
\hline $\begin{array}{l}\text { ポリエステル } \mathrm{S} \\
\text { ポリエステル } \mathrm{F} \\
\text { アクリル } \mathrm{S} \\
\text { ナイロン } \quad \mathrm{F}\end{array}$ & NA & NA & $\begin{array}{l}45 \\
44 \\
33 \\
26\end{array}$ & $\begin{array}{l}54 \\
63 \\
38 \\
31\end{array}$ & $\begin{array}{l}57 \\
71 \\
45 \\
37 \\
\end{array}$ \\
\hline $\begin{array}{l}\text { ポリエステル短繊維織物 } \\
\text { ポリエステル長繊維織物 }\end{array}$ & NA & $\mathrm{NA}$ & $\begin{array}{l}4.7 \\
65\end{array}$ & $\begin{array}{l}53 \\
74\end{array}$ & $\begin{array}{r}67 \\
\text { NA }\end{array}$ \\
\hline
\end{tabular}

＊2000年におけるアジア地域（日本を含む）の瀻維生産量の世界シェアは約 $60 \%$ となる.

(出所 : 化纎協会, 東京コンサルティング, 繊維ハンドブック)

化すれば，アジア絨維貿易は大きく混乱し，中長期 的にはアジアの緘維産業の発展を阻害する懸念もあ る.この需給ギャップの解消のためには, アジア各 国での内需拡大が最重要な課題にあげられている. この中で, 中国の経済成長が今後 $9 \%$ 以上で推移す れば, 2000 年におけるアジア地域の需給ギャップは おおむね解消されるという試算がある.

このように1985年プラザ合意を契機に, 繊維生産 基地は，日本からアジア NIES，アジア NIES から ASEAN へ, 1990年代に入ってからは, 舞台は中国, ベトナムに移行してきている．このような動きを通 して, アジア諸国の生産基盤が拡大することによっ て, 高度成長を達成, それに伴って, 所得の向上,
消費の拡大・高度化が進展, アジア全体が質・量と あにスパイラル的に拡大する図式が生まれている.

\section{ASEAN の繊維・アパレル産業の発展}

ASEAN 諸国は近年目覚ましい発展を遂げている が, その要因として具体的には以下の点が挙げられ る.

(1)豊富で相対的に安い労働力の存在.

(2)日本, NIES 等の国際競争力が衰え，これらの 国から ASEAN への生産拠点の移転が急テン ポで進んだこと.

(3)自国通貨の切り下げ等, 国際競争力環境の改善 に対応して, 現地資本が果敢な新増設を行った 
表 3 アジアの緎維需要と人口の推移

（単位：需要・万トン／人口; 億人）

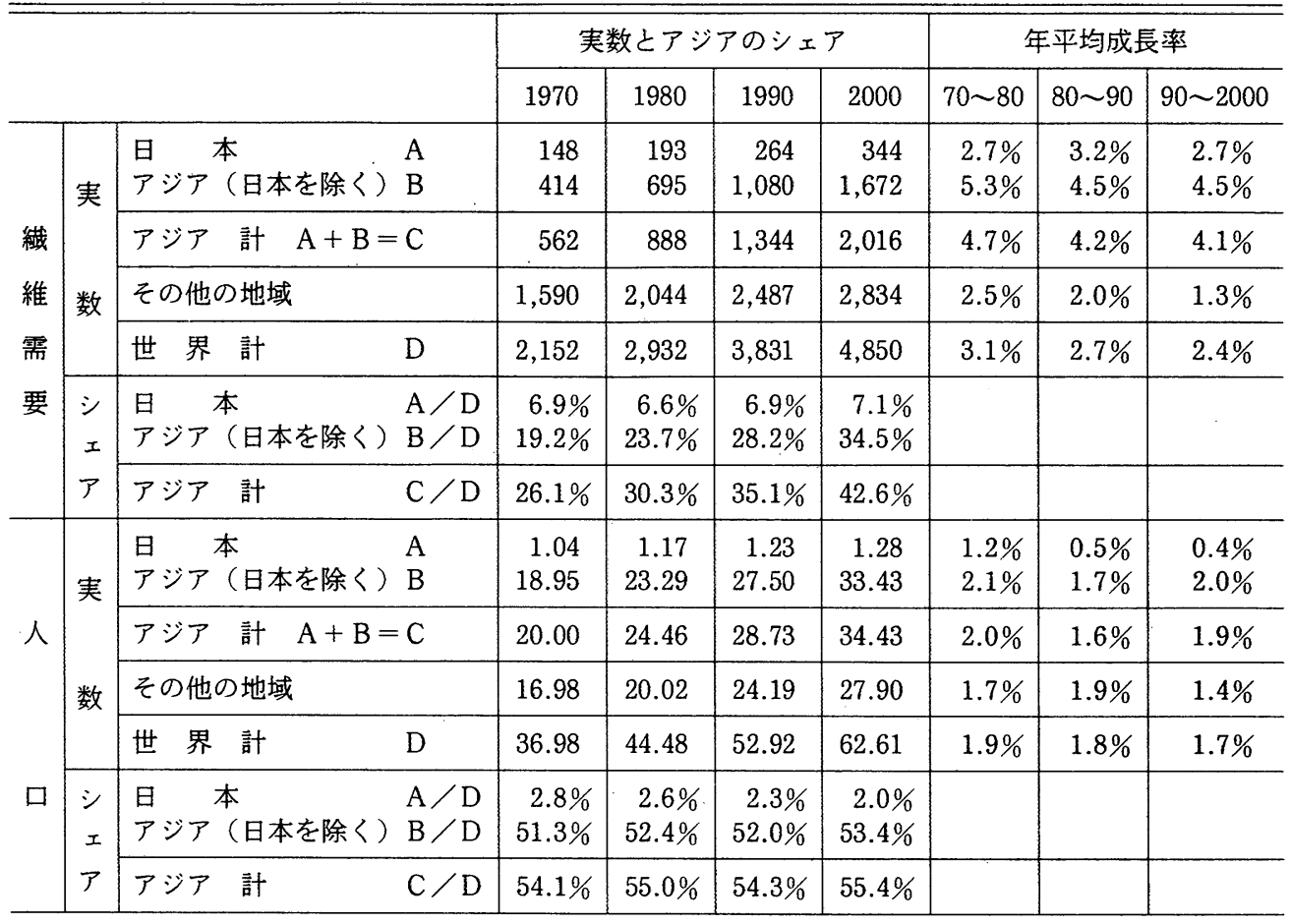

（注）繊維需要は合繊・レーヨン・綿花・羊毛の合計. 2000 年は化繊協会予測.

（出所：化繊協会「緎維需要」，国連統計「人口」，東京コンサルティング分析）

こと.

(4)欧米向けクォーターに依然余裕があったこと.

(5)また，品質向上努力が確実に成果をあげている こと.

この結果, ASEAN の繊維品輸出は, 1980年代後 半から90年代にかけて急激に増大し, ASEAN 5 か 国の綫維輸出の単純合計は表 4 に示したように, 1985年の30億ドルから1992年で170億ドルに達し, 全体としてすでに韓国を上回り中国に接近しつつあ る. 特に，アパレル製品輸出については，韓国，台 湾などがアパレル製品輸出が頭打ちとなって, 糸, 繊維など中間製品にシフトしているのに対し, ASEANにおいては，1985年の20億ドルから1992年 の114億ドルへとタイ，インドネシアを中心に，大き く伸びてきているのが特徴であり，中国，香港には 及ばないものの，ASEAN 全体として，急速にその シェアを拡大しつつある。しかむ, インドネシア, タイを中心として, 川上から川下部門まで設備の新 増設意欲は依然旺盛であり, 世界の繊維産業の中 で，ASEAN は中長期的にさらに競争力を高めてい
くあのと予想されている.

しかし，ASEAN のなかであ，国別にはそれぞれ の人口規模, 発展段階等により, 賃金の上昇, 人手 不足, 商品開発力, 技術力, 人材育成等, 種々の課 題を抱えており，今後対応すべき方向は一様ではな い.しかし，これら多くの課題を抱えつつも，将来 の発展を期する ASEAN 諸国の努力は着実に，その 成果を実現しつつあるように思える.

\section{ASEAN のアパレル産業の直面する課題}

\section{（1）技術者，中間管理職の育成}

家電など他産業との競合が激しい中で, 学卒エン ジニア, 中間管理職の安定供給が期待できず, 企業 内での育成が必要であるが, 特に, これらの層の定 着性に問題があり，技術の継承上問題が生じている ケースが少なくない，このだめ, 品質管理等の水準 は総じて低く，依然改善の努力が必要である。

\section{(2) 商品開発力の向上}

国際市場で通用する独自の力による商品開発力 は，依然十分とはいえない，NIESに比へ相対的に 
表 4 世界主要国の瀻維翰出額 (単位 : 億ドル)

\begin{tabular}{|c|c|c|c|c|c|c|}
\hline 国名 年 & $\begin{array}{l}\text { テキス } \\
\text { '85 }\end{array}$ & $\begin{array}{l}\text { イル } \\
\text { '92 }\end{array}$ & $\begin{array}{l}\text { 衣 } \\
\text { '85 }\end{array}$ & $\begin{array}{l}\text { 料 } \\
\text { '92 }\end{array}$ & $\begin{array}{l}\text { 合 } \\
\text { '85 }\end{array}$ & $\begin{array}{l}\text { 計 } \\
\text { '92 }\end{array}$ \\
\hline インドネシア & & 28.7 & & & & 60 \\
\hline & & & & & & \\
\hline シンガポール & & 10.8 & & & & 28.9 \\
\hline マレーシア & & & & & & 25.3 \\
\hline フィリピン & & 1.2 & & & & 9.4 \\
\hline 合 & & 56.8 & 19.9 & 114 & 31.3 & 171.0 \\
\hline 韓 & & ? & & & & \\
\hline 台 & & & & & & \\
\hline 国 & & 85.8 & 19 & 16 & & 20 \\
\hline 日 & & 70 & & & & 71.0 \\
\hline アメリ & 14.6 & 46.0 & & & & 93.2 \\
\hline $\mathrm{E}$ & 208.9 & 463.8 & 138.7 & 394.6 & 347.6 & 858.4 \\
\hline
\end{tabular}

(出所 : GATT)

表 5 䋊維輸出額伸び率および翰出に占める割合

\begin{tabular}{c|c|c|c|c}
\hline \hline 国名 年 & $85 / 80$ & $90 / 85$ & $92 / 90$ & 㵶維輸出/総翰出(92) \\
\hline インドネシア & $343 \%$ & $501 \%$ & $156 \%$ & $13.4 \%$ \\
タ & 207 & 379 & 128 & 14.9 \\
シンガポール & 203 & 278 & 117 & 4.7 \\
マレーシア & 71 & 662 & 129 & 5.5 \\
フィリピン & 86 & 238 & 104 & 8.5 \\
\hline 合 計 & 166 & 381 & 131 & 8.7 \\
\hline
\end{tabular}

（出所 : IMF, Statistics）

表 6 アセアンの繊維品翰出のシェア（91年）

\begin{tabular}{c|c|c}
\hline \hline 国名 & 世界シェア & 日欧米依存度 \\
\hline インドネシア & $2 \%$ & $60 \%$ \\
タ イ & 2 & 52 \\
シンガポール & 1 & 55 \\
マレーシア & 1 & 80 \\
フィリピン & 1 & 82 \\
\hline 合 計 & 7 & 60 \\
\hline
\end{tabular}

(出所 : GATT)
表 7 アセアン各国の繊維加工設備 （92年/単位: 紡續機は1，000鍾，他は 1,000 台）

\begin{tabular}{l|c|c|c}
\hline \hline 国名 機種 & 紡績機 & 織 機 & 編 機 \\
\hline インドネシア & 6,000 & 158 & 17.3 \\
タ & 3,500 & 135 & 85 \\
シンガポール & & 1 & 0.5 \\
マレーシア & 500 & 9 & 3.0 \\
フィリピン & 1,420 & 22 & 3.7 \\
\hline
\end{tabular}

(出所 : 化緎協会)

表 8 アセアン各国の繊維労働者平均貨金（米ドル/月９2年 3 月）

\begin{tabular}{c|rr|c|c|c|c}
\hline \hline インドネシア & タ & イ & マレーシア & フィリピン & (中 国) & (ベトナム) \\
\hline 45 & 120 & 236 & 135 & 73 & 50 \\
\hline
\end{tabular}

(出所 : 化瀻協会) 
表 9 実質国民総生産額平均伸び率

\begin{tabular}{l|c|c|c|cc}
\hline \hline 国名 & 年 & $1980-85$ & $1985-90$ & $1990-93$ & \multicolumn{1}{|c}{ 中長期国家計画 } \\
\hline インドネシア & $4.3 \%$ & $7.1 \%$ & $6.6 \%$ & $6.6 \%$ & $(94-98)$ \\
タ & 5.4 & 9.5 & 8.8 & 8.2 & $(92-96)$ \\
シンガポール & 6.8 & 6.4 & 7.9 & 4.0 & $(89-2030)$ \\
マレーシ ア & 5.5 & 5.5 & 8.5 & 7.5 & $(91-95)$ \\
フィリピン & 0.5 & 2.8 & 0.8 & 8.3 & $(94-98)$ \\
\hline
\end{tabular}

表10 中長期国家計画における 1 人当たり国民総生産額

\begin{tabular}{|c|c|c|c|c|c|}
\hline & 叫 & '85 & רים & \multicolumn{2}{|c|}{ 中長期国家計画 } \\
\hline 国名 & 别 & 00 & YL & 初年度 & 終年度 \\
\hline インドネシア & $\begin{array}{l}\text { 生産額（米ドル）／人 } \\
\text { 人口／百万人 }\end{array}$ & 468 & 640 & $\begin{array}{l}743(94) \\
189.1\end{array}$ & $\begin{array}{c}1,088(98) \\
204.4\end{array}$ \\
\hline 夕 & $\begin{array}{l}\text { 生産額（米ドル）／人 } \\
\text { 人ロ／百万人 }\end{array}$ & 1,076 & 1,701 & $\begin{array}{l}1,701(92) \\
56.9\end{array}$ & $\begin{array}{c}3,778(96) \\
61.0\end{array}$ \\
\hline シンガポール & $\begin{array}{l}\text { 生産額（米ドル）／人 } \\
\text { 人口／百万人 }\end{array}$ & 10,951 & 17,216 & $\begin{array}{c}14,036(89) \\
3.2\end{array}$ & $\begin{array}{c}49,837(2030) \\
3.4 \sim 4.4\end{array}$ \\
\hline マレーシア & $\begin{array}{l}\text { 生産額（米ドル）／人 } \\
\text { 人ロ／百万人 }\end{array}$ & 1,964 & 2,718 & $\begin{array}{l}2,471(91) \\
18.0\end{array}$ & $\begin{array}{c}4,016(95) \\
20.3\end{array}$ \\
\hline フィリピン & $\begin{array}{l}\text { 生産額（米ドル）／人 } \\
\text { 人ロ／百万人 }\end{array}$ & 588 & 601 & $\begin{array}{l}631(94) \\
68.3\end{array}$ & $\begin{array}{l}794(98) \\
75.1\end{array}$ \\
\hline
\end{tabular}

表11 衣料品輸入額 (単位 : 百万米ドル)

\begin{tabular}{|c|c|c|c|c|c|}
\hline 国名 年 & 1985 & 1990 & 1992 & $90 / 85$ & $92 / 90$ \\
\hline インドネシア & 4 & 16 & 30 & $400 \%$ & $250 \%$ \\
\hline タ イ & 1 & 10 & 24 & 1,000 & 240 \\
\hline シンガポール & 297 & 920 & 1,193 & 310 & 130 \\
\hline マレーシア & 45 & 76 & 80 & 169 & 105 \\
\hline フィリピン & 3 & 13 & 24 & 433 & 185 \\
\hline 合 & 350 & 1,035 & 1,351 & 296 & 131 \\
\hline
\end{tabular}

(出所 : GATT)

賃金水準が低いとはいえ，インドネシア以外の諸国 では，賃金水準も相当程度高くなり，かつ急激に上 舁しつつある。このため，価格競争力のみに依存し た場合には，ASEAN を追跡する中国・ベトナムお よび南西アジアとの競合がますます激化することが 予想される．今後これらの国々に対抗するため，お よびノンクォーター市場の開拓のためにあ，デザイ ン開発力等; 商品開発力を高め, より高い付加価値 ゾーンへの移行が必要である.

インドネシアのバティックに代表されるように, ASEANにはもともと優れた伝統的なデザイン力を
有しておりここの伝統のデザインを新しいファッシ ョンに取り込んで, すでに海外においてデザイナー ブランドとして，浸透しつつあるあのあみられる が，依然，限られた範囲に止まっている．今後これ らの伝統も生かしつつ, 新しい商品開発による差別 化，高級化の努力が期待される.

（3）海外市場開拓とそれに対応できる生産・流通 体制の整備

ASEAN 各国ともノンクォーター市場の開拓に努 力しつつあるが，グローバルな情報収集力を高め, マーケットそれぞれの特徵を的確に把握し, 対応し ていく必要がある.

さらに, マーケット需要の変化に即応した生産管 理, 納期管理体制の確立のためには，素材・付属品 などの輸入，および製品デリバリーに要する期間の 短縮化が重要であり, 流通のさらなる合理化や輸出 入通関手続の一層の簡素化，迅速化が望まれる.

\section{ベトナム,インドなどの動向}

今後はベトナム, ラオスなどのインドシナ諸問題 
表12 世界の織維消賽量（1990年）

\begin{tabular}{|c|c|c|c|c|c|c|}
\hline 年 & \multicolumn{3}{|c|}{ 消實量（1000トン） } & \multicolumn{3}{|c|}{$\mathrm{kg} /$ 人 } \\
\hline 国名 & '85 & '90 & $(90 / 85)$ & '85 & '90 & $(90 / 85)$ \\
\hline インドネシア & 329 & 481 & (146) & 1.9 & 2.9 & (152) \\
\hline & 146 & 209 & $(143)$ & 2.8 & 4.2 & (150) \\
\hline シンガポール & 75 & 77 & (103) & 21.6 & 30.3 & (140) \\
\hline マレーシア & 101 & 90 & ( 89$)$ & 6.9 & 5.9 & ( 86$)$ \\
\hline フィリピン & 90 & 182 & (202) & 1.4 & 3.4 & (242) \\
\hline 計 & 741 & 1,039 & (140) & 2.6 & 3.7 & (142) \\
\hline & 2,149 & 2,676 & (125) & 17.8 & 22.2 & (125) \\
\hline 国 & 600 & 836 & (139) & 12.8 & 20.6 & (161) \\
\hline 国 & 5,736 & 5,828 & (102) & 5.1 & 5.7 & (112) \\
\hline & 68 & 83 & (122) & 11.5 & 15.2 & (132) \\
\hline U. S. & 5,397 & 6,169 & (114) & 22.6 & 25.3 & (112) \\
\hline & 5,129 & 6,483 & (126) & 15.9 & 19.1 & (120) \\
\hline 世界合計 & 33,481 & 37,024 & (111) & 7.0 & 8.1 & (116) \\
\hline 先 進 & 20,279 & 22,406 & (111) & 16.7 & 21.6 & (129) \\
\hline 発 展 途上国 & 13,212 & 14,618 & (111) & 3.7 & 3.8 & (103) \\
\hline
\end{tabular}

(出所 : FAO)

に対しては, 委託加工という形態でのリンケージを 強めるとともに，当面はNIES の瀻維産業の補完的 な役割を高めていくと思われる.

インド，パキスタンについては，インドは内需向 け中心に生産シェアを拡大, パキスタンは綿系, 綿 織物の生産輸出を漸増, 文化, 社会体制の異質性か ら，外資の積極的進出には時間はかかろうが，印僑 ネットワークが活発化し，急速に設備投資を進める 動きも出てきている.

韓国, 台湾は合繊とポリエステル長繊維織物で, 中国市場成長に伴う中国向け輸出拡大を見込んで大 幅な能力増を図っており, 中国の内需の成長ペー ス, 自給化の動向により大きく影響を受ける構造と なっている。

中国は, 巨大な内需と豊富で低廉な労働力に支え られて, 繊維の生産, 消費全般にわたる繊維大国と なる. 内需拡大と同時にアパレル輸出を拡大するた め, 合繊（原糸, 原綿）と長繊維織物については, 輸入ポジションを継続することが必要であり，その 輸入幅の増減がアジア全体の需給バランスに影響す るであろう。

\section{アジア繊維産業の共存共栄のための対話}

\section{（1）アジア地域における各国間対話の必要性}

将来のアジア繊維産業の発展, そのためのアジア
繊維産業の分業体制の構築を円滑に推進するために は, 分野別, 品種別, あるいはそれらを総合した形 で相互の交流を保ち, 将来の各国の瀻維産業像につ いて相互に理解し合う努力が必要である.

また，現時点でみられるような過剩設備投資の結 果としての, 無秩序な生産および輸出は, アジア地 域の緎維産業・市場・貿易に混乱を生じせしめるこ ととなるが，このような事態に対しては，国際協定 に則った貿易秩序化措置のルール化等の対応を図っ ていくことあ必要であろう.

このような事態を回避するためには,アジア各国 がアジア地域を含む世界の需給動向について現実的 な見通しに関する情報を相互に提供し合い，各国に おける生産量が極端に過度なものとならないように 努力する必要がある.

なお，アジア各国の中には, 統計が未整備である 分野屯多く, 今後, 各国においては, 統計整備に努 める必要がある.このためには, 我が国としてあ, 各国の統計整備のために協力することが必要であろ う.

（2）共存共栄のためのアジア各国間対話のスタート 今回のアジア繊維ビジョンで描いた 2000 年のアジ ア各国の繊維産業像は, 我が国において入手可能で あった統計資料等に基づき, 我が国繊維産業の従事 者, 有識者による議論を通じてとりまとめたもので 
ある。

今後,このアジア繊維ビジョンを契機にアジア各 国においてもそれぞれの立場, 認識からの将来のア ジア繊維産業像が提示され, それをもとにアジア各 国間でアジア繊維産業全体の発展が実現されるよう 話し合いが行われることが期待される.

このためには，アジア地域の各国間で現在行われ ている各種業界会談を進化, 発展させ, 総合的な意 見交換の場を創設することを検討することも一案で あろう。

重要なことは, アジア繊維産業の発展, 国際分業, 共存共栄のためには, 各国の纎維産業の健全な発展 が不可欠であり, その中で今後とも我が国繊維産業 の役割は大きいということである. 古畑＼cjkstart昭郎（こばたあきろう） 昭和 30 年中央大学法学部卒, 同 年(保センイ・ジャァナル入社, 同 51 年加ら編集局長, 業務局 長，中部支社長を歴任，同58年 取締役, 同62年常務取締役, 平 成元年東京支社長, 同 4 年専務 取締役を経て，同 5 年代表取締 役社長に就任, 現在に至る。(怑) センイ・ジャァナル， $\mathbf{\top} 530$ 大 阪市北区天神西町 4-12, TEL. 06-364-2731, FAX. 06-3642740)

\section{海外資料研究部会入会ご案内}

世界各国の繊維技術情報を

$$
\begin{array}{r}
\text { より早く, より広く, より正確に把握するために } \\
\text { 海外資料研究部会へご入会下さい }
\end{array}
$$

本学会海外資料研究部会におきましては, 海外各国から, 我が国にもたらされる, 繊維に関する数多くの情報を遂 一検討し，それらを工程別，分野別に分類，整理の上，速や汃に訳出し，「海外縅維技術文献集」を通じて定期的にお とどけしています。

世界各国における研究状況，技術開発および市場動向等，いち早くその関連業界の流れを的確に把握するため，本 研究部会へのご入会をおすすめします.

\section{1，海外文献，資料の蒐集整備}

\section{事 業 内 容}

海外各国より毎月 100 数種の文献, 資料, 所報, 社報, カ夕ログ等を入手しており, これらの整備充実をはかり, そ の内容を訳出して会員に紹介しています.

\section{2. 海外繊維技術文献集 (月刊) の刊行}

毎月入手する多数の文献や資料等をそれぞれの分野の専門の委員によって，工程別に分類，整理の上，速やかに訳 出して紹介する海外織維文献抄録之, 繊維並びに繊維機械に関する基礎的研究論文, 実際的研究及び新製品や新しい 技術の紹介等, 比較的重要と思われるものについては全訳して紹介する海外䋐維技術文献集を合冊して, 機関誌とし て定期的におとどけします。

編集, 訳出, 查読等は全国各大学, 研究所並びに会社所属の専門の方々に依頼し, その正確流暢を期しています.

3. 海外文献紹介講演会, 座談会の開催

海外文献に掲載されたもののうち注目すべきもの, あるいは海外で行われた講演会, シンポジウム並びに見本市等 につき，随時紹介講演会，座談会を開催します。

\section{4. 海外文献, 資料の複写頒布}

会員に限り, 本会所有の文献, 資料の複写頒布を行っています.

5. 申込方法

申込書をご請求下さい.

購読料 1 部1.600円（消費税，送料込み） 部会費（割引購䛃料）年間12,360円（消費税込み）

厂550 大阪市西区勒本町 1-8-4 (大阪科学技術センタービル)

日本繊維機械学会 海外資料研究部会 (T E L。06-443-4691)

(F A X. 06-443-4694) 